УДК 691.175.743

\title{
ПРИМЕНЕНИЕ НЕФТЯНЫХ КОКСОВ В ДРЕВЕСНО-ПОЛИМЕРНЫХ КОМПОЗИТАХ НА ОСНОВЕ ПОЛИЭТИЛЕНА
}

\author{
Хантимиров Аяз Габдрашитович \\ аспирант \\ Ахсянов Азат Наилевич \\ магистр
}

\section{Хайруллина Карина Ильшатовна}

студент

Научный руководитель: Абдрахманова Ляйля Абдулловна д.т.н., профессор ФГБОУ ВО «Казанский государственный архитектурно-строительный университет»

Аннотация: невысокие значения эксплуатационных характеристик древесно-полимерных композитов на основе полиэтилена подталкивают исследователей к поиску новых эффективных связующих агентов. В данном исследовании представлены результаты модификации ДПК на основе ПЭ наноразмерными нефтяными коксами с различными степенями механоактивации.

Ключевые слова: полиэтилен, древесно-полимерный композит, углеродные наноструктуры, связующий агент.

\section{THE USE OF PETROLEUM COKES IN WOOD-POLYMER COMPOSITES BASED ON POLYETHYLENE}

\section{Khantimirov Ayaz Gabdrashitovich Akhsyanov Azat Nailevich Khairullina Karina Ilshatovna Abdrakhmanova Lyailya Abdullovna}

\footnotetext{
Abstract: low values of performance characteristics of wood-polymer composites based on polyethylene push researchers to search for new effective
} 
coupling agents. This study presents the results of modification of PE-based DPCs with nanosized petroleum coke with different degrees of mechanoactivation.

Key words: polyethylene, wood-polymer composite, carbon nanostructures, coupling agent.

Самым популярным полимером для производства древесно-полимерных композиций (ДПК) является полиэтилен (ПЭ), который с точки зрения простоты переработки значительно превосходит полипропилен и поливинилхлорид (ПВХ) [1, с. 65]. Полиэтилен в отличие от других полимеров имеет широкий диапазон вязкостей расплава и низкую температуру плавления, что позволяет использовать древесный наполнитель без риска его деструкции [2, с. 16].

Однако ДПК на основе ПЭ имеют высокую эластичность и небольшие прочностные характеристики, что ограничивает область применения данных изделий в строительстве [3, с. 43].

Для комплексного улучшения свойств в ДПК применяют связующие агенты (совместители), которые способствуют образованию более прочных связей на границе «древесный наполнитель - полимер».

Влияние различных связующих агентов для ПЭ изучено довольно широко, среди них хорошо зарекомендовали себя добавки на основе наноразмерных технических углеродов.

В работе [4, с. 79] в полимерные композитные материалы на основе ПЭВП был введен технический углерод с размером частиц 20-35 нм. Улучшение таких показателей как прочность на разрыв, деформация разрыва, электропроводность и предел текучести расплава наблюдалось в диапазоне $12-18 \%$ масс.

Авторами [5, с. 1072] были изучены составы основе ПЭ, модифицированные фуллеренсодержащим техническим углеродом. Фуллерены $\left(\mathrm{C}_{50}-\mathrm{C}_{92}\right)$ содержались в наполнителе в количестве $10 \%$ масс. В результате испытаний было установлено увеличение прочности при разрыве в 1,5 раза при введение фуллеренсодержащего углерода до 1,5 масс.ч, однако, одновременно уменьшился показатель текучести расплава, что говорит о повышении вязкости.

В работе [6, с. 88] рассмотрены причины эффекта усиления материалов при введении технического углерода. Так, усиление можно объяснить 
наличием ван-дер-ваальсовых сил взаимодействия между атомами углерода в частицах модификатора и полимерных цепей, а также межфазным взаимодействием за счет наличия свободных радикалов на поверхности частиц технического углерода, которые инициируют процесс химической сшивки на границе раздела фаз.

Таким образом, актуальной задачей является поиск эффективных связующих агентов на основе углеродных наноструктур для ПЭ, которые к тому же имели бы невысокую стоимость.

В данной работе качестве наномодификаторов были использованы механоактивированные отходы переработки нефтяных коксов, представляющие собой мелкодисперсные порошки черного цвета.

Целью данной работы явилось исследование влияния коксов с различными степенями механоактивации на физико-механические свойства древесно-полимерных композитов на основе ПЭ.

Композиции состоят из ПЭНД марки ПЭ2НТ11-285Д (ТУ 20.16.10-17500203335-2017)), древесной муки марки 180 (ГОСТ 16361-87) и нефтяных коксов с разными степенями механоактивации: 1,34 мэкв/г (кокс 1) и 0,57 мэкв/г (кокс 2). Концентрация наномодификаторов была выбрана согласно результатам ранее проведенных исследований ДПК на основе ПВХ [7, c. 153].

Таблица 1

Составы ДПК

\begin{tabular}{|c|c|c|c|}
\hline \multirow{2}{*}{ Компонент } & \multicolumn{3}{|c|}{ Состав } \\
\cline { 2 - 4 } & $\mathbf{1}$ & $\mathbf{2}$ & $\mathbf{3}$ \\
\hline ПЭНД, мас.ч. & \multicolumn{3}{|c|}{100} \\
\hline Древесная мука (ДМ), мас.ч. & \multicolumn{3}{|c|}{50} \\
\hline Кокс 1, \% от массы ДМ & - & 0,1 & - \\
\hline Кокс 2\%, от массы ДМ & - & - & 5 \\
\hline
\end{tabular}

Образцы в виде плоских профилей были получены на лабораторном экструдере LabTechScientific LTE 16-40 с плоскощелевой фильерой сечением $2 \times 22$ мм. Температурный режим экструдирования по зонам рабочего цилиндра показан в таблице 2. 
Таблица 2

Температурный режим экструдирования

\begin{tabular}{|c|c|c|c|c|c|c|c|c|c|c|}
\hline Зоны цилиндра & 1 & 2 & 3 & 4 & 5 & 6 & 7 & 8 & 9 & 10 \\
\hline Температура, $^{\mathbf{0}} \mathbf{C}$ & 183 & 183 & 183 & 185 & 190 & 190 & 190 & 195 & 195 & 200 \\
\hline
\end{tabular}

Полученные образцы были подвергнуты комплексным испытаниям на физико-механические свойства, результаты которых представлены в таблице 3 .

\section{Таблица 3}

Свойства модифицированных ДПК

\begin{tabular}{|c|c|c|c|}
\hline \multirow{2}{*}{ Показатель } & \multicolumn{3}{|c|}{ Составы } \\
\cline { 2 - 4 } & $\mathbf{1}$ & $\mathbf{2}$ & $\mathbf{3}$ \\
\hline Прочность на растяжение, МПа & 19,7 & 21,4 & 21,4 \\
\hline Прочность при изгибе, МПа & 32,6 & 38,7 & 34,1 \\
\hline Истирание, мкм & 50 & 50 & 49 \\
\hline Водопоглощение, \% & 3,05 & 1,76 & 2,20 \\
\hline Средняя плотность, г/см ${ }^{3}$ & 1,01 & 1,04 & 1,04 \\
\hline Разбухание (по толщине) & 0,975 & 0,972 & 0,956 \\
\hline
\end{tabular}

Из представленных данных видно, что модифицированные композиции имеют повышенные значения прочностных характеристик. Так, прочность при растяжении для всех модифицированных композитов возрастает на 9\%, а прочность при изгибе с коксом 1 на 19\%. Кроме того, в образцах с модификаторами значения водопоглощения уменьшились для кокса 1 и кокса 2 на 73 и $39 \%$ соответственно по сравнению с исходными результатами, что коррелирует с данными по плотности и разбуханию. Показатели истирания остаются на уровне немодифицированной композиции. По комплексу свойств оптимальной добавкой является кокс 1 в количестве $0,1 \%$ от массы древесной муки, что объясняется большим количеством кислородосодержащих групп на поверхности частиц по сравнению с коксом 2. 
Таким образом, осуществлено введение механоактивированных нефтяных коксов в качестве связующих агентов в древесно-полимерных композитах на основе ПЭ.

Введение кокса 1 в количестве $0,1 \%$ повышает прочность при растяжении на $9 \%$, при изгибе на $19 \%$ и снижает водопоглощение на $73 \%$. В композициях с содержанием кокса 2 в количестве 5\% также увеличивается прочность при растяжении на 9\%, а водопоглощение снижается на $39 \%$. Кроме того, отмечено положительное влияние модификаторов на плотность и разбухание. В целом, комплексное улучшение характеристик позволяет рекомендовать механоактивированные коксы в качестве эффективных связующих агентов.

\section{Список литературы}

1. Клесов А.А. Древесно-полимерные композиты / А.А. Клесов. - СПб.: Научные основы и технологии, 2010. - 736 с.

2. Файзуллин И.З. Вольфсон С.И. Древесно-полимерные композиционные материалы на основе полипропилена и модифицированного древесного наполнителя // Монография. - Казань: Изд-во КНИТУ. - 2020. $106 \mathrm{c}$.

3. Вольфсон С.И., Мусин И.Н., Файзуллин И.З., Лыгина Ф.А., Трофимова Ф.А. Модифицированные древесно-полимерные композиты // Пластические массы. - 2014. - № 1-2. - С. 41-44.

4. Борукаев Т.А., Гаев Д.С. Физико-механические свойства композитов на основе полиэтилена высокой плотности и технического углерода // Прикладная физика. - 2017. - № 5. - С. 76-81.

5. Игуменова Т.И., Клейменова Н.Л., Акатов Е.С., Попов Г.В. Применение фуллеренсодержащего технического углерода для модификации свойств полиэтилена // Вестник ТГТУ. - 2011. - Том 17. - № 4. - С. 1071-1076.

6. Свистков А.Л., Солодько В.Н., Кондрюрин А.В., Елисеева А.Ю. Гипотеза о роли свободных радикалов на поверхности наночастиц технического углерода в формировании механических свойств наполненного каучука // Физическая мезомеханика. - 2016. - Том 19. - № 5. - С. 84-93.

7. Абдрахманова Л.А., Галеев Р.Р., Хантимиров А.Г., Хозин В.Г. Эффективность углеродных наноструктур в составе древесно-полимерных 
композитов на основе поливинилхлорида // Нанотехнологии в строительстве. - 2021. - № 13(3). - C. 150-157.

(C) А.Г. Хантимиров, А.Н. Ахсянов, К.И. Хайруллина, 2021 